\title{
Why Putting Yourself in the Mind of Your Reader Is Easier-and More Challenging- Than You Might Have Imagined
}

COMMUNICATION CORNER

\author{
by Philip Yaffe
}

\section{Editor's Introduction}

Each "Communication Corner" essay is self-contained; however, they build on each other. For best results, before reading this essay and doing the exercise, go to the first essay "How an Ugly Duckling Became a Swan," then read each succeeding essay. 


\title{
Why Putting Yourself in the Mind of Your Reader Is Easier-and More Challenging- Than You Might Have Imagined
}

\author{
COMMUNICATION CORNER
}

\author{
by Philip Yaffe
}

Writers are constantly exhorted to "put yourself in the mind of the reader" and "write from the reader's point of view." Unless the reader feels that one's own interests and apprehensions are being catered for, chances are the reader will rapidly lose interest and stop reading. Worse, they might read the entire text only to conclude that doing so was a waste of time.

All of this is sound advice. The problem is, while we may think we are writing from the reader's point of view, often we aren't. Not because we don't want to, but because we have never been taught how.

One of the most important techniques for achieving the objective is the $Q$ \& $A$ (questions and answers) technique. As you read, questions about the text are constantly being raised in your mind. Most often these questions are subconscious. However, the more questions that accumulate in the back of the mind, the less the text seems to really be saying anything of interest.

The $Q$ \& $A$ technique requires the writer to immediately answer these unconscious questions or as soon as possible after they are raised.

The importance of this and how to achieve it can best be demonstrated by example. Newspaper reporters are masters at applying the $Q \& A$ technique; if they weren't, few people would bother to read newspapers. Below is part of an article taken from a major international newspaper. First, we will look at the article, and then analyze it in terms of $Q$ \& $A$.

Original

The Pink Paper, Britain's longest running free weekly gay newspaper, has gone into bankruptcy after 17 years. Barazoka, one of the world's oldest gay magazines, also seems likely to cease publication after more than 30 years of being sold in Japan. 
Both publications cite the same three reasons for their demise: rising gay use of the internet, falling advertising revenues, and increasing coverage of gay news in the "respectable" press.

Readership of Barazoka, which began publication in 1971, rapidly rose and remained high for two decades; however, in the past five years its circulation has fallen to just 10 percent of what it was in the 1990s. Issue $\mathrm{N}^{\circ} 382$, scheduled for publication next week, will probably be its last.

The final issue of The Pink Paper, $\mathrm{N}^{\circ} 859$, was printed on October 1 . The newspaper was founded in 1987 specifically to battle against plans of the Conservative Party government of Margaret Thatcher to introduce Section 28, a law that prohibited the "promotion" of homosexuality.

The fight was won when the law was repealed under the Labor Party government of Tony Blair in the late 1990s.

Over the years, The Pink Paper reported extensively on other gay equality issues such as the ban on gays in the military, same-sex marriages, and adoption by gay couples.

(The story continues for several more paragraphs.)

\section{Analysis}

The Pink Paper, Britain's longest running free weekly gay newspaper, has gone into bankruptcy after 17 years. Barazoka, one of the world's oldest gay magazines, also seems likely to cease publication after more than 30 years of being sold in Japan.

Question: Why are these newspapers going bankrupt? The answer is in the next paragraph.

Both publications cite the same three reasons for their demise: rising gay use of the Internet, falling advertising revenues, and increasing coverage of gay news in the "respectable" press.

Question: How bad did the situation get? The answer is in the next paragraph.

Readership of Barazoka, which began publication in 1971, rapidly rose and remained high for two decades; however, in the past five years its circulation has fallen to just 10 percent of what it was in the 1990s. Issue $\mathrm{N}^{\circ} 382$, scheduled for publication next week, will probably be its last.

The final issue of The Pink Paper, $\mathrm{N}^{\circ} 859$, was printed on October 1 . The newspaper was founded in 1987 specifically to battle against plans of the Conservative Party government of Margaret Thatcher to introduce Section 28, a law that prohibited the "promotion" of homosexuality. 
Question: What was the result of The Pink Paper's battle against Section 28? The answer is in the next paragraph.

The fight was won when the law was repealed under the Labor Party government of Tony Blair in the late 1990s. Over the years, The Pink Paper reported extensively on other gay equality issues such as the ban on gays in the military, same-sex marriages, and adoption by gay couples.

\section{Detailed Analysis}

This story is an excellent example of many aspects of good expository writing, so it is worth looking at in detail.

The Pink Paper, Britain's longest-running [1] free weekly gay newspaper, has gone into bankruptcy after 17 years. Barazoka, one of the world's oldest [2] gay magazines, also seems likely to cease publication after more than 30 years of being sold in Japan.

1. "Longest-running" is a weasel word, raising the question of just how long is long. The answer "17 years" comes at the end of the same sentence.

2. "Oldest" is also a weasel word, raising the question of just how old is old. The answer "more than 30 years" comes later in the same sentence.

Both publications cite the same three reasons for their demise: rising gay use of the internet, falling advertising revenues, and increasing coverage of gay news in the "respectable" press.

Readership of Barazoka, which began publication in 1971, rapidly rose and remained high for two decades; however, in the past five years its circulation has fallen to just 10 percent of what it was in the 1990s. Issue $\mathrm{N}^{\circ} 382$, scheduled for publication next week, will probably be its last.

Note all the precise information in this paragraph, including the number of Barazoku's final issue $\left(N^{\circ} 82\right)$. This clearly tells readers that the writer knows what he is talking about.

The final issue of The Pink Paper, $N^{\circ} 859$ [1], was published on October 1 . The newspaper was founded in 1987 specifically to battle against the plans of the Conservative Party government [2] of Margaret Thatcher to introduce [3] Section 28, a law that banned the "promotion" of homosexuality.

1. Once again, note the number of The Pink Paper's final issue ( $\left.N^{\circ} 859\right)$.

2. Not just "the government" but "the Conservative Party government." This helps readers better understand what the political/social climate was like when the paper was founded. Recalling that Margaret Thatcher was in power further helps readers better understand the political/social climate of the time. 
3. Not just "a law that banned promotion of homosexuality," but "Section 28, , its specific name.

The fight was won when the law was repealed under the Labor Party government [1] of Tony Blair [2] in the late 1990s. Over the years, The Pink Paper reported extensively on other gay equality issues such as the ban on gays in the military, same-sex marriages, and adoption by gay couples.

1. Not just "the government" but "the Labor Party government." This helps readers better understand what the political/social climate was like when Section 28 was repealed.

2. Recalling that Tony Blair was in power further helps readers better understand the political/social climate of the time.

Most people take their daily newspapers for granted. However, experienced writers know that they are the best source of inspiration for writing well no matter what genre of writing they wish to engage in. As evidence, here is a short list of noted novelists who began as journalists: Charles Dickens, Arthur Conan-Doyle, Graham Greene, Ernest Hemingway, John Hersey, Jack London, H.L. Mencken, George Orwell, George Plimpton, Ayn Rand, Will Self, Upton Sinclair, John Steinbeck, James Thurber, J.R.R. Tolkien, Mark Twain, E.B. White, Walt Whitman, Tom Wolfe, P.G. Woodhouse, and many others.

\section{HOMEWORK: Retrospective to Communication Corner No. 5}

As you saw in Communication Corner No. 5, making full use of the two hot spots in each sentence is one of the quickest, easiest ways to improve your writing. You were then given a few exercises for using the technique. Specifically, you were asked to revise some sentences to ensure that the hot spots are used to their full advantage. As with most things in writing and speaking, there is more than one way to make an improvement.

The important thing is to know what you are doing and why you are doing it, as you will see below.

\section{Exercise 1}

[Original]

In the presence our company's chairman, the new bio-science research center built at a cost of $\$ 75$ million was inaugurated yesterday. 
[Revisions]

1. The new $\$ 75$ million bio-science research center was inaugurated yesterday. In the presence of our company's chairman ... (more info on the inauguration).

2. The new bio-science research center, built at a cost of $\$ 75$ million, was inaugurated yesterday. In the presence of our company's chairman ... (more info on the inauguration).

Note the word "yesterday" still remains at the end of the first sentence in both revisions. In most cases this would be an error, "yesterday" being a detail that does not merit the hot spot at the end of the sentence. However, in this case putting it anywhere else would have made the transition to the rather clumsy phrase "In the presence of our company's chairman..." considerably more awkward.

Also note the placement of the $\$ 75$ million cost of the new facility. In the first revision, it is used almost like an adjective in describing the new research center. In the second revision, it is in a separated phrase (in grammar known as an appositive), which gives the cost of the facility greater emphasis.

\section{Exercise 2}

[Original]

Hillary Clinton fired back at the official Republican Party Twitter account after it asked for her to specify her healthcare plan on Wednesday.

[Revisions]

1. Hillary Clinton Wednesday fired back at the official Republican Party Twitter account after it asked for her to specify her healthcare plan.

2. Hillary Clinton fired back Wednesday at the official Republican Party Twitter account after it asked for her to specify her healthcare plan.

3. Hillary Clinton fired back at the official Republican Party Twitter account Wednesday after it asked for her to specify her healthcare plan.

4. On Wednesday, Hillary Clinton fired back at the official Republican Party Twitter account after it asked for her to specify her healthcare plan.

Note the differences in the four revisions.

In the first three revisions, the word 'Wednesday" is put inside the sentence rather than in the hot spot at the end. The position of Wednesday in the three sentences gives a slightly different emphasis, but there is really very little to choose among them. 
In the fourth revision, Wednesday is placed at the beginning of the sentence, but in a short dependent clause ("On Wednesday"). Why? In order to put greater emphasis on the main clause "Hillary Clinton fired back at the official Republican Party Twitter account...."

Remember: There is more than one way to improve a sentence. The important thing is to know what you are doing and why you are doing it.

\section{Exercise 3}

[Original]

I claim to be ignorant and proud of it, but rather than being proud of my lack of knowledge I am proud of recognizing just how much knowledge I lack.

[Revisions]

1. I claim to be ignorant and proud of it. But rather than being proud of my lack of knowledge, I am proud of recognizing just how much knowledge I lack.

2. When I claim to be ignorant and proud of it, I am not talking about being proud of my lack of knowledge but rather my recognition of just how much knowledge I lack.

Note how in the first revision, dividing a single sentence into two separate sentences can strengthen the message. The two separate sentences together say exactly the same thing as the original, but the effect is decidedly different.

The second revision uses an introductory dependent clause, "When I claim to be ignorant and proud of it," which strengthens the impact of the main clause, "I am proud of recognizing just how much knowledge I lack...."

Both revisions, like the original, are strengthened by judicious repetition of the key words "proud," "knowledge," and "lack," almost like a drum roll.

\section{Exercise 4}

Here is a longer, and therefore more complex exercise. At first glance, the following text may already appear to be fairly well written. However, it could be considerably improved. Use everything you have learned about clear $(C l=E D E)$, concise $(C o=L S)$, dense $(D=P L)$ writing, the $5 \mathrm{Ws} \& \mathrm{H}$, the inverted pyramid, and hot spots to make it even better.

[Original]

Oxford University has once again petitioned the High Court to protect its buildings and staff from animal rights activists. It is asking that a temporary exclusion zone, in force since last month, be made permanent until a full civil trial on the matter can take place. 
The "no harassment" boundary prohibits protesters from going within 35 meters of university property.

University officials said that work on its new $£ 18$ million bio-medical research laboratory was stopped in July because contractors were being intimidated by animal rights activists. Animal testing to be carried out in the facility would be 98 percent on rodents with the remaining 2 percent on amphibians, fish, ferrets and primates.

[Revision]

Oxford University has renewed its battle with animal rights activists by petitioning for a High Court injunction to limit protests, which university officials said have stopped construction work on its new bio-medical research laboratory since July. The $f 18$ million facility would use animals for testing with 98 percent of experiments on rodents and the remaining 2 percent on amphibians, fish, ferrets and primates.

The university claimed that the activists are intimidating contractors working on the new facility. It wants a temporary exclusion zone, in force since last month, to be made permanent until a full civil trial on the matter can take place. The "no harassment" boundary prohibits protesters from going within 35 meters of university property.

Note: The revision passes the "Stop Reading Test." Readers can stop reading after the first paragraph and still have a clear, sharp picture of what the story is about. If they wish to know more, they can continue reading, but they don't have to. The choice is theirs.

Busy people very much appreciate this kind of writing. Such people have neither the time nor the desire to read the entirety of every text put before them. What they want is for the writer to clearly identify what they must read. Any additional material they may wish to read should be left to their own judgment.

For information on how to achieve this very economical kind of writing, review Communication Corner No. 3: "How to Improve Your Writing by Standing on Your Head."

\section{CURRENT HOMEWORK}

The following texts appear to be satisfactorily well written, and they are. However, they could be considerably improved. The problem here is not missing information, but how the information is organized. Re-order the information to boost the impact of the texts. Pay particular attention to using the $Q$ \& $A$ (question and answer) technique to ensure that the text passes the "Stop Reading Test." 


\section{Exercise 1}

An on-board tracking device operating via the mobile phone system will make it possible for insurance companies to monitor the driving behavior of their customers.

Stored in the back of the vehicle, the device will record the roads on which the motorist is travelling and the time of the journey, and send the information to the insurance company.

The company will then calculate the insurance premium based on an assessment of the relative risk of crashes on the different roads at different times of the day. Motorists will receive a monthly or quarterly "usage statement", similar to a telephone bill, giving the insurance cost for each journey.

By agreeing to the system, motorists could save hundreds of dollars on their automobile insurance.

Trips on superhighways will cost less per kilometre than on city roads because they have lower crash rates.

\section{Exercise 2}

Venezuelan President Hugo Chavez has survived a national vote of confidence in his leadership, winning 58 percent of the vote. His supporters immediately celebrated the victory in a predawn rally by exuberantly chanting, "Chavez isn't leaving!"

Señor Chavez's victory claim was supported by Jimmy Carter, the former U.S. president and head of a team of international observers. Information collected by the team "coincided with the partial results announced this morning by the National Electoral Council," Mr. Carter said.

Opposition leaders quickly denounced the official result as fraudulent and called on their supporters to protest in the streets of Caracas, the capital, and throughout the country.

\section{About the Author}

Philip Yaffe was born in Boston, Massachusetts, in 1942 and grew up in Los Angeles, where he graduated from the University of California with a degree in mathematics and physics. In his senior year, he was also editor-in-chief of the Daily Bruin, UCLA's daily student newspaper. He has more than 40 years of experience in journalism and international marketing communication. At various points in his career, he has been a teacher of journalism, a 
reporter/feature writer with The Wall Street Journal, an account executive with a major international press relations agency, European marketing communication director with two major international companies, and a founding partner of a specialized marketing communication agency in Brussels, Belgium, where he has lived since 1974. He is the author of more than 20 books, which can be found easily in Amazon Kindle.

DOI: $10.1145 / 3178861$ 